76 巻 768 号 $(2010-8)$

\title{
エスカレーター踏段のライザー形状に関する一考察*
}

$\begin{array}{lllll}\text { 小倉 } & \text { 学*1, 治 田 康 } \text { 雅*2 }^{*} \text { 吉 川 達 也象, 喜 成 年 } & \text { 泰*4 }\end{array}$

\section{Consideration on Riser Shape of Escalator Step}

\author{
Manabu OGURA*5, Yasumasa HARUTA, \\ Tatsuya YOSHIKAWA and Toshiyasu KINARI \\ ${ }^{* 5}$ Human Resources Development Center, Mitsubishi Electric Corp., \\ 8-1-1 Tsukaguchi Honmachi, Amagasaki-shi, Hyogo, 661-8661 Japan
}

\begin{abstract}
The comb structure between cleats in adjoining steps is one of the safety features in escalators. It prevents the biting of shoes, hands and feet between adjoining steps. This comb structure is between the riser cleat in the upper side step and the demarcation comb in the lower side step. Now, the depth of overlap of the comb structure in the upper side of the riser is gradually reduced over that in the lower side of the riser to make for easy exit when shoes, hands or feet are bitten between steps. This method greatly contributes to the prevention of nasty accidents. On the other hand, this ease in exit also makes it easier to be bitten in the upper side of the riser. Therefore, as one idea, safety improvement by making it more difficult to be bitten by deepening the engaging in the upper side of the riser is a likely area for study. In this paper, the riser cleat shape and step composition are examined with the view that "it should not ever be easy for shoes to be bitten between steps". As a result, if you follow this view, the overlap depth should be enlarged in the upper side of the riser.
\end{abstract}

Key Words: Elevator, Mechanism, Design, Safety Engineering, Escalators, Safety Device, Comb Structure, Steps, Riser Cleat Shape, Overlap Depth

\section{1. 緒}

エスカレーターは，不特定多数の一般人が利用する という機器の性格上，安全性には十分な配慮がなされ ている. そのような安全対策の一つに，踏段クリート （突起）やコム（櫛歯構造）相互の噛み合わせ構造が ある．噛み合わせ構造は，踏段の踏板上面クリートと エスカレーター乗降部のコムとの間，および，隣接す る踏段の下段側踏段踏板前端部之上段側踏段ライザ一 (蹴上げ部) クリートとの間に設けられており，これ ら相対運動を行う構造物間の隙間部分へ靴先等力噛夕 込むことの防止を目的としている.この噛み合わせ構 造によって，隙間部分への噛み込み事故に対する安全 性は極めて高いものとなっているが，残念ながら，噛 み込み事故を完全に防止することはできていない.

現状の踏板前端部-ライザークリート間の噛み合わ せ構造は，踏段間の段差が小さくなるに従い噛夕合わ せが徐々に浅くなる形状となっており ${ }^{(1)}{ }^{(2)}$,靴先など

* 原稿受付 2010 年 2 月 22 日.

*1 正員, 三菱電機(株)人材開発センター(需 661-8661 尼崎市 塚口本町 8-1-1)

*2 正員, 三菱電機 (株) 穱沢製作所 (画 492-8682 稲沢市菱町 1)

*3 三菱電機 (株) 稲沢製作所.

*4 正員, 金沢大学理工研究域機械工学系 (要 920-1192 金沢市 角間町).

E-mail : Ogura.Manabu@ab.MitsubishiElectric.co.jp
か踏段間の隙間に一旦噛み込んでも，段差が小さくな ると抜けやすくなる特性を有している．この特性が重 大事故の未然防止に大きく貢献している. 一方，この 噛み合わせを浅くしていくことによる抜け易さは，噛 み込み易いことを意味しており，この観点から，従来 とは逆に，段差の縮小に伴い噛名わせを深くするこ とにより噛み込み難くさを向上させるという安全対策 にも検討の余地力残つていると考えられる.

そこで，本論文では，従来とは見方を変え，“噛み込 み難さの向上”という視点に立ち, 単に通常動作時の 㖥み込み難さの改善を図るためにライザー上部（踏段 間段差の小さい領域）の噛夕合わせを大きくするだけ ではなく、いたずら等により，踏段が浮き上がった場 合の歯み込み難さの改善を図るという観点からも，踏 板前端部とライザークリートの噛み合せ（ライザーク リートの形状）をどのようにすればよいかについての 理論検討を行う。

\section{2. エスカレーターの踏段構造と 䟞み込みメカニズム}

$2 \cdot 1$ エスカレーターの構造と動作 図 1 は，工 スカレーター全体と踏段部分の構成図である. エスカ レーターの各構成要素は，トラスと呼ばれる主枠に組 みつけられている. トラスの上部と下部に配置された 
上部スプロケット，下部スプロケット間には踏段チェ ーンが巻き掛けられており，これを駆動ユニットで駆 動することで踏段チエーンに結合された踏段が循環移 動する. 踏段の両側面には, 駆動ローラ(Step chain roller) と追従ローラ(Trailing roller)が設けられており，それら をそれぞれ，駆動レール(Main track), 追従レール (Trailing track)で案内することにより，踏段の軌道と姿 勢が制御される.すなわち，乗降口部では，踏段の踏 面が水平にならび，一定傾斜部では，踏段か階段状と なり，その間の上下曲部 (図 1中, M,N の部分) では, 踏段の段差が変化しながら走行する。

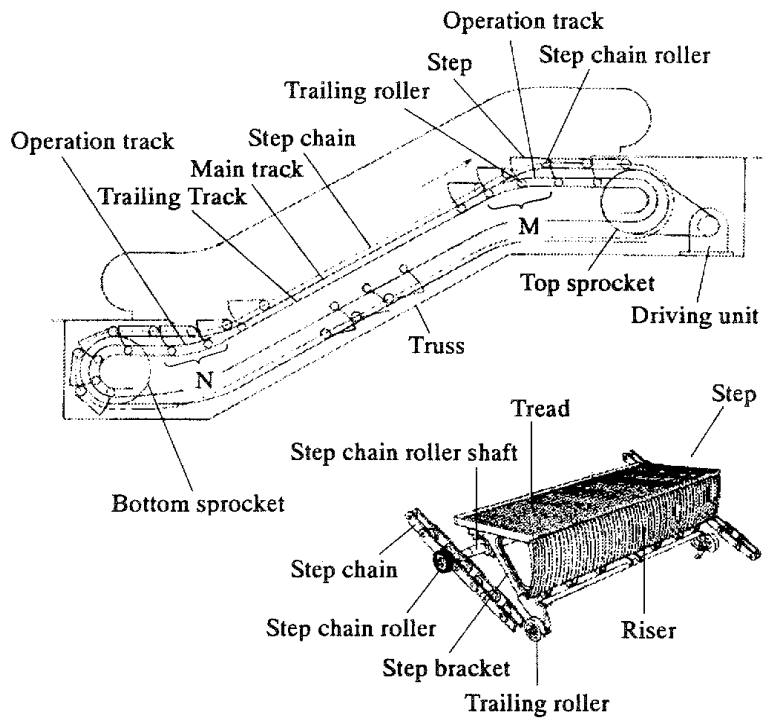

Fig.1 Complete schematic of escalator

前述したように，踏段の踏板とライザーには，多数 のクリート (突起) が設けられている. 踏板に設けら れたクリートの前端部（デマコム： demarcation comb） は，ライザークリートとの間で梳き上げ構造（噛み合 わせ構造）を構成している. また，前述したように， 各踏段は，駆動ローラを支持する駆動ローラ軸（Step chain roller shaft）を介して踏段チェーンに連結されてい るため, 上下の曲部では，隣接する踏段の同一相当部 位か駆動ローラ軸間の距離を半径とした相対円運動を 行うように段差が変化する. さらに，踏段と駆動口ー ラの間は回転自由となっていることから, 踏段のライ ザ一側は駆動ローラを中心に回転する（浮き上がる） ことが可能な構造となっている.

$2 \cdot 2$ 踏段間への齫み込みメカニズム 以上のよ うに構成されたエスカレーターでは，隣接する踏段間 の梳き上げ構造部に靴先等か噛み込むことが稀にある. この噛み込みメカニズムを図 2 を用いて説明する. 図2
は，上昇運転時の上曲部における搭乗踏段（下段側踏 段）とその上段側の踏段の相対運動を表す概略側面図 である. この場合の相対運動を上段側踏段を基準にし て考えると，搭乗踏段が上段側踏段に対し，踏段上の 同一相当部位が円運動を行うように矢印 $z$ の方向に相 対変位する。このため, 搭乗踏段の踏板前端コ一ナ一 部の移動軌跡は，上段側踏段の踏板前端コ一ナ一部を 中心とし, 半径か溤動ロ一ラ軸間の距離 $r_{\mathrm{D}}$ の円弧とな る. 踏段間への噛夕込久事故は，この相対運動中に， 搭乗踏段に乗った利用者の靴先等が上段側踏段のライ ザーに押付けられている場合に発生する。

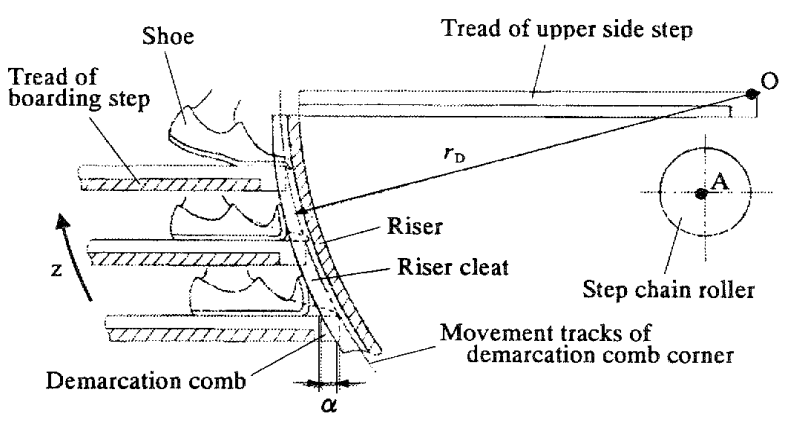

Fig.2 Relative motion between boarding step and upper side step

第 1 の噛み込みメカニズムは，図に示しているよう に，ライザークリート表面と靴の裏側あるいは先端と の摩擦力により，ライザークリート間に喰い込んでい た靴先が下方に曲げられ，踏板前端部とライザークリ 一トの間の梳き上げ構造部に噛み込んでしまうという ものである. また，第 2 の噛み込みメカニズムは，靮 先等のライザーへの押付け力が一定值以上であるとき， ライザークリート表面と靴の裏側との摩擦力により, 上段側踏段のライザ一側が浮き上がって, 踏板前端部 とライザークリートの噛夕合わせ代 $\alpha$ が小さくなり

(開口部ができることもある), 梳き上げ効果が低下し て, 踏板前端部とライザークリートの間に靴先か噛み 込んでしまうというものである.

従来の踏段の梳き上げ構造においては，靴先等が噛 み込んだ場合，拔晹くするとの配慮から，踏板前端 部とライザークリートとの噛夕合い代 $\alpha$ がライザーの 下部で大きく，上方へいくほど小さくなるように構成 されており，これが逆に，ライザー下部に比ベライザ 一上部での梳き上洨効果を低下させるというトレード オフの関係となっている. したがって, 従来とは考え 方を変えて “噛み込み難さの向上”を目的とした安全 対策を施すと仮定した場合, 第 1 の噛み込みメカ二ズ 
ムについてのみ対策するのであれば，梳き上げ効果の 向上を図るべく，単純にライザ一上部における噛み合 い代 $\alpha$ を大くすれば良いことは明らかである．しか し,この対策が，第 2 の歯み込みメカニズムに対する対 策, すなわち, 踏段が浮き上がった場合の啮み合い代 $\alpha$ の減少を抑える方向になっているのかどうかを確認 する必要がある.

そこで，次章では，第 1 の噛み込みメカニズム（上 段側踏段が浮き上がらない場合）の対策となる，ライ ザ一上部の䊝み合い代 $\alpha$ を大さする場合のライザー クリートの設計方針を明らかにするとともに，第 2 の 噛み込タメカニズム（上段側踏段が浮き上がる場合） の対策として，ライザークリート形状がどうあるべき なのかを明確化する.

\section{3. ライザークリート表面形状の設計方針}

$3 \cdot 1$ 上段側踏段か浮き上がらない場合 図 3 は, 踏段の段差が小さくなる場合の搭乗踏段の踏板前端コ 一ナ一部の移動軌跡と上段唄踏段ライザークリートの 表面形状との位置関係を表す概略図である(踏板前端 部とライザークリートが噛み合っている). 踏段間段差 が樎小する際, 隣接踏段は同一相当部位が相対円運動 し，また通常，側面から見たライザークリートの表面 形状は円弧となっていることから, 踏板前端コ一ナー 部の移動軌跡と上段側踏段ライザークリート表面形状 は, 原点 $\mathrm{O}$ (上段側踏段の踏板前端コ一ナ一部) を中 心とする半径 $r_{\mathrm{D}}$ の円弧と, 任意の点 $\mathrm{E}(c, d)$ を中心 とする半径 $r_{\mathrm{F}}$ の円弧として表すことができる. 搭乗踏 段踏板前端コーナ一部の移動軌跡上の任意の点を D $\left(x_{\mathrm{D}}, y_{1}\right)$, 点 $\mathrm{D}$ と $\mathrm{y}$ 座標が等しいライザークリート表 面上の点を $\mathrm{F}\left(x_{\mathrm{F}}, y_{1}\right)$ とおけば，それぞれの点は，

$$
\begin{aligned}
& x_{D}^{2}+y_{1}^{2}=r_{D}^{2} \\
& \left(x_{F}-c\right)^{2}+\left(y_{1}-d\right)^{2}=r_{F}^{2}
\end{aligned}
$$

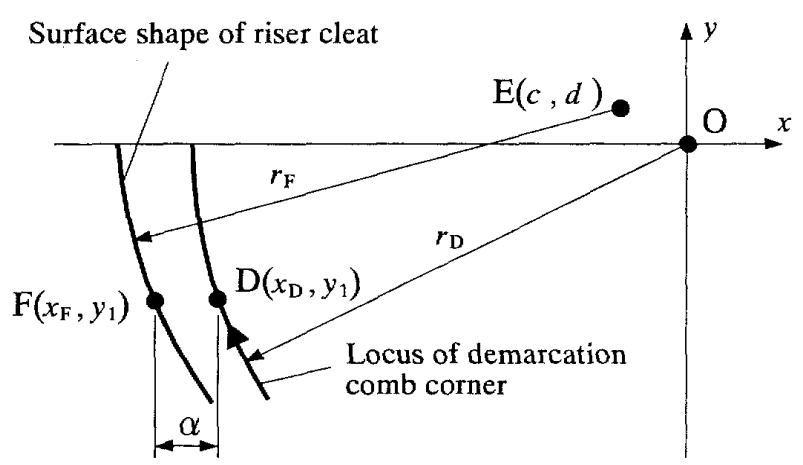

Fig.3 Relation between demarcation comb comer and surface shape of riser cleat
という式を満足する. よって，これらの式から，上段 側の踏段が浮き上がらずに，搭乗踏段と上段側踏段の 段差が縮小していく場合の踏板前端コ一ナ一部の高さ $y_{1}$ におけるライザークリートと踏板前端との噛み合い 代 $\alpha$ は,

$$
\begin{aligned}
\alpha & =x_{D}-x_{F} \\
& =-\sqrt{r_{D}^{2}-y_{1}^{2}}-c+\sqrt{r_{F}^{2}-\left(y_{1}-d\right)^{2}}
\end{aligned}
$$

である．上段側踏段が浮き上がらずに通常の状態で搭 乗踏段と上段側踏段の段差が栄小していく場合の膦み 合い代 $\alpha$ の大きさの変化を評価するためには，踏板前 端コ一ナ一部の高さ $y_{1}$ の変化に対する $\alpha$ の変化の感度, すなわち， $\alpha$ の $y_{1}$ に関する微分值に着目すれば良い. 式(3)を $y_{1}$ で偏微分した値を $s$ とおけば,

$$
s=\frac{\partial \alpha}{\partial y_{1}}=\frac{y_{1}}{\sqrt{r_{D}^{2}-y_{1}^{2}}}-\frac{y_{1}-d}{\sqrt{r_{F}^{2}-\left(y_{1}-d\right)^{2}}}
$$

となる. ライザ一上部の噛み込みにくさ（梳き上げ効 果) をライザー下部と同等かそれ以上にするためには， $y_{1}$ の增加に対し噛み合い代 $\alpha$ 一定か增加するように すればよいから， $\mathrm{n} \geqq 0$ であれば良い。したがって，

$$
\frac{y_{1}}{\sqrt{r_{D}^{2}-y_{1}^{2}}}-\frac{y_{1}-d}{\sqrt{r_{F}^{2}-\left(y_{1}-d\right)^{2}}} \geq 0
$$

となる. ここで, $r_{\mathrm{F}}=k r_{\mathrm{D}}$ とおけば, $y_{1} \leqq_{0}$ であることか ら, 現実的な解として,

$$
d \geq(1-k) y_{1}
$$

が得られる.この式は, ライザーの上部へいくほど噛 み合い代 $\alpha$ か定か大きくなるために円弧中心 $\mathrm{E}$ の $y$ 座標 $d$ がとるべき值の範用を示すものであるが, $y_{1}$ が とる全範囲にわたって式(6)を満足するようにdの值を 定める必要があることには注意を要する.

図 4〜6は, 式(4)から， $r_{\mathrm{D}}=400 \mathrm{~mm}$ としたときの $d$ と $s$ の関係を, $y_{1}$ をパラメータとして示したグラフである.

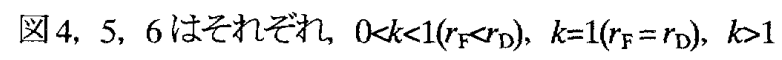
$\left(r_{\mathrm{F}}>r_{\mathrm{D}}\right)$ の場合の一例として, $k=0.9, k=1.0, k=1.1$ の場 合を示している. ここで, $y_{1}$ の範囲は-200 $\mathrm{mm} \leqq y_{1} \leqq 0$ としている.

これらの図と式(6)とから， $y_{1}$ の増加に対し噛み合い 代 $\alpha$ が増加する（ $(\geqq 0$ となる）dの範囲を求めると, $0<k<1$ の場合には， $y_{1}=0$ のときに $d$ の取り得る範用が 最も狭くなり，すべての $y_{1}$ の範囲で式(5)が満足される のは, $d \geqq 0$ の場合となる. また, $k=1$ の場合には, $y_{1}$ 


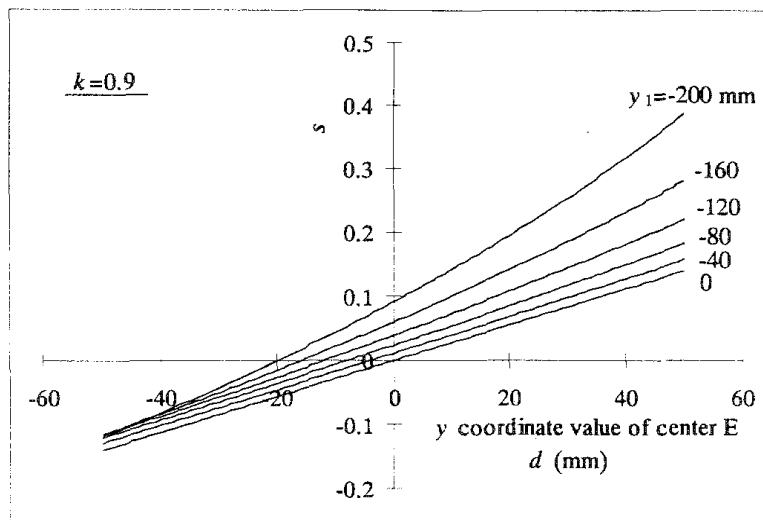

Fig.4 Relation between $d$ and $s$ when parameter is $y_{1} \quad(\mathrm{k}=0.9)$

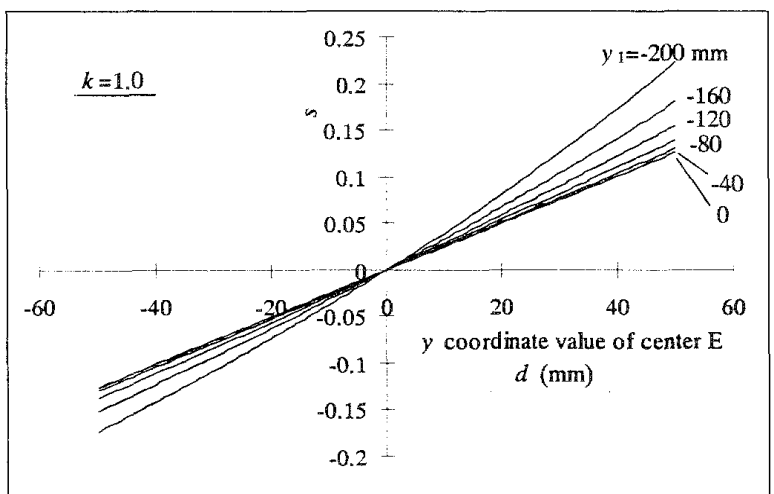

Fig.5 Relation between $d$ and $s$ when parameter is $y_{1} \quad(\mathrm{k}=1.0)$

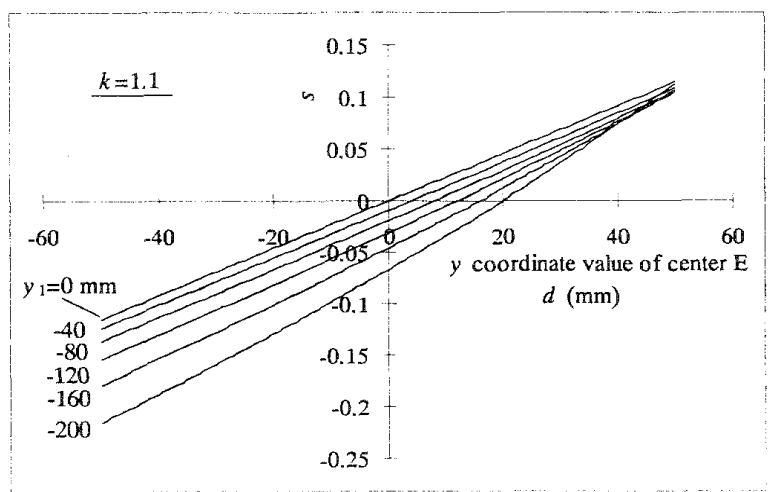

Fig.6 Relation between $d$ and $s$ when parameter is $y_{1} \quad(k=1.1)$

の值によらず， $d \geqq 0$ が求める $d$ の範囲となるが, $d=0$ の場合には， $s=0$ となり，噛み合い代 $\alpha$ は增加しない。 さらに, $k>1$ の場合には, $y_{1}=y_{\min }(=$ ライザー下端の $y$ 座標，ここでは-200）のときに $d$ の取り得る範用が最 も狭くなり，すべての $y_{1}$ の範讲で式(5)が満足されるの は, $d \geqq(1-k) y_{\min }>0$ の場合である。
以上の検討により，上段側踏段が浮き上がらない場 合におけるライザー上部の噛み込み難さを向上（梳き 上げ効果を向上）させるための，即ち，ライザ一上部 へいくほど踏板前端コ一ナ一部とライザークリートの 噛み合わせを深くするための基本的な設計方針（ライ ザークリート表面形状の円弧中心 $\mathrm{E}$ の $y$ 座標の定め方) が明らかとなった．実際のライザークリートを設計す る際のテクニックとして，ライザーの上部へ行くほど ある踏段間段差までは水平噛み合い代 $\alpha$ を増加させ， その位置より段差が小さい範囲については，噛み合い 代を一定とするという方法も取り得る.

$3 \cdot 2$ 上段側踏段か浮き上がる坦合 図 7 は，靴 先のライザーへの押付け等により，上段側踏段が浮き 上がる場合の搭乗踏段と上段側踏段の相対的な位置関 係を示す概略図である. エスカレーターの上下曲部M， $\mathrm{N}$ （図 1）て踏段の段差が絔小する場合，通常，踏段の 踏面注水平を維持した状態であるが，前述したように， 上段側踏段のライザーに靴先等が一定力以上で押付け られると，踏段間の段差縮小がロックされるため，上 段側の踏段のライザー側が駆動ローラの回転中心 A を 中心に浮き上がる. そして，上段側踏段のライザーク リートと搭乗踏段の踏板前端部との間隔 $p$ は広がる(広 がることを前提としているため，前項での噛み合い代 $\alpha$ とは逆に，間隔が広がる方向を正としている. ライ ザークリートと踏板前端部が啮み合っている場合, $p$ は負となる．以後，踏段間隔 $p$ と呼ぶ)。

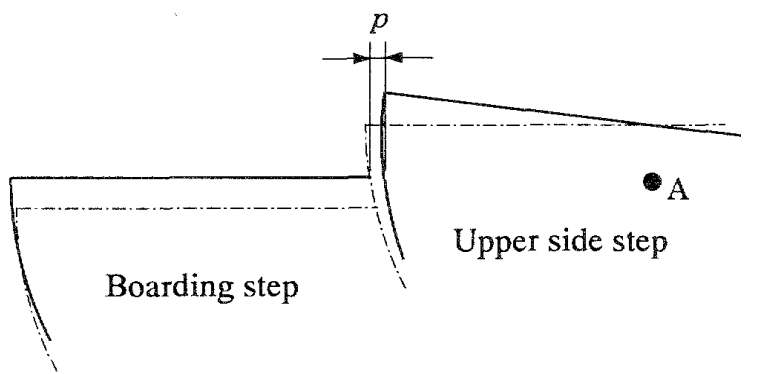

Fig.7 Relative position relation between boarding step and upper side step when the step lifts

以下，上段側踏段が浮き上がる場合の搭乗踏段踏板 前端コ一ナ一部の高さ方向の位置と踏段間隔 $p$ との関 係について詳細に述べる。

図 8 は，上段側踏段が浮き上がる場合の踏段間隔 $p$ を説明するための概略図である。座標の原点 $\mathrm{O}$ に搭乗 踏段踏板前㟨コ一ナ一部の回車移動中心点（上段側踏 段踏板前端コ一ナ一部）をとり，搭乗踏段踏板前端コ 一十一部の移動軌跡 (半径 $r_{\mathrm{D}}$ )上に任意の点 D $\left(x_{\mathrm{D}}, y_{1}\right)$ 


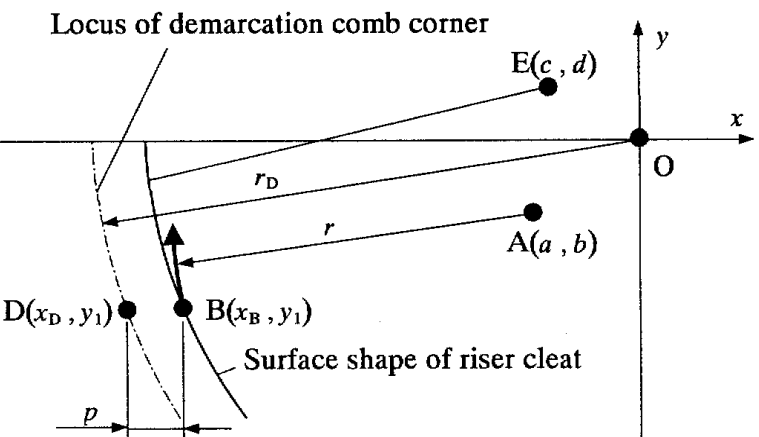

Fig.8 Outline figure to express gap between steps $p$ when the step lifts

をとる. エスカレーターの上下曲部 $\mathrm{M}, \mathrm{N}$ (図 1）で踏 段間の段差が小さくなるときに，搭乗踏段が下方（ $y$ 軸の負の方向）から上昇し，搭乗踏段踏板前端コ一ナ 一部が点 $\mathrm{D}$ の位置にきたときに靴先の押付けなどによ り踏段間の段差の縮小がロックされたとすると，点 D と $y$ 座標值が等しい上段儧踏段のライザークリート表 面上の点 B $\left(x_{\mathrm{B}}, y_{1}\right)$ 怄，駆動口ーラの回転中心 A 6 , b) を中心に点D と $y$ 座標が一致するように回転移動(半 径 $r$ ）乙上昇する. このときの関係を式で表すと,

$$
\begin{aligned}
& x_{D}^{2}+y_{1}^{2}=r_{D}^{2} \\
& \left(x_{B}-a\right)^{2}+\left(y_{1}-b\right)^{2}=r^{2} \\
& p=x_{B}-x_{D}
\end{aligned}
$$

となる.よって，式(7)から，

$$
x_{D}=-\sqrt{r_{D}^{2}-y_{1}^{2}}
$$

であり, 式(8)と，基本的に $x_{\mathrm{B}}<a$ であることから，

$$
x_{B}=a-\sqrt{r^{2}-\left(y_{1}-b\right)^{2}}
$$

である. したがって，式(9)，(10)，(11)より，踏段間隔 pは,

$$
p=a-\sqrt{r^{2}-\left(y_{1}-b\right)^{2}}+\sqrt{r_{D}^{2}-y_{1}^{2}} \quad \cdots
$$

\section{となる.}

図 9 中の濃い線は， $a=-60 \mathrm{~mm}, b=-80 \mathrm{~mm}, r_{\mathrm{D}}=400 \mathrm{~mm}$ の場合に $r$ をパラメータとして,$y_{1}$ と $p$ との関係を示 したものである. $p$ が負の場合は踏板前端部とライザー クリートが噛み合っている. また，図中の薄い線は， $c=-5 \mathrm{~mm}, d=5 \mathrm{~mm}, r_{\mathrm{F}}=400 \mathrm{~mm}$ の場合の上段側踏段が浮 き上がらない場合の $y_{1}$ と $p$ (=初期踏段間隔 $p_{0}$ : 踏段が 浮き上がらない場合の踏段間隔）との関係を示したも のである. ライザークリート表面の駆動ローラ回転中

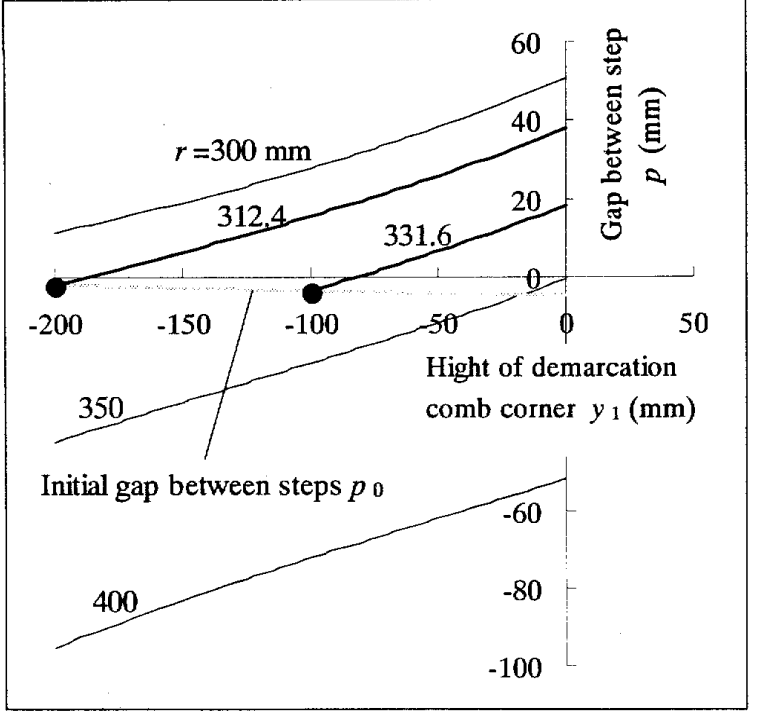

Fig.9 Relation between $y_{1}$ and $p$ when parameter is $r$

心Aからの距離 $r$ は

$$
r=\sqrt{\left\{a-c+\sqrt{r_{F}^{2}-\left(y_{1}-d\right)^{2}}\right\}^{2}+\left(y_{1}-b\right)^{2}}
$$

として求められ，この值は $y_{1}$ によって異なるため, 段 差の縮小がどの位置でロックされるかによってその後 の踏段間隔の広がり方に違いが生じる. 図 9 中の $r=312.4 \mathrm{~mm}$ と $331.6 \mathrm{~mm}$ のケースは，それぞれ， $y_{1}$ が $-200 \mathrm{~mm}$ と-100mm の位置で段差の縮小がロックした場 合の踏段間隔の広がり方を示したものである.

段差の縮小がロックした後の上段側踏段の浮き上が りに伴う踏段間隔 $p$ の変化を評価するためには， $y_{1}$ の 変化に対する $p$ の変化の感度, すなわち, $p$ の $y_{1}$ に関 する微分值 $q$ （踏段間隔拡大感度）に着目すれば良い. そこで, 式(12)を $y_{1}$ で偏微分した值 $q$ を求めると,

$$
q=\frac{\partial p}{\partial y_{1}}=\frac{y_{1}-b}{\sqrt{r^{2}-\left(y_{1}-b\right)^{2}}}-\frac{y_{1}}{\sqrt{r_{D}^{2}-y_{1}^{2}}}
$$

となる. 図 10 は, 各定数の值が図 9 を求めた場合と同 様としたときの $r$ をパラメータとした $y_{1}$ と $q$ との関係 を示したものである. $r$ を変えることにより $y_{1}$ と $q$ の関 係は大きく変化するが, どの曲線も $y_{1}=b$ の位置で $q$ は 同一值 $q_{\mathrm{b}}$ となる.

$$
q_{b}=-\frac{b}{\sqrt{r_{D}^{2}-b^{2}}}(=0.204)
$$

実際のエスカレーターでは，安全装置か装着されてお $り^{(3)}$, 踏段が大きく浮き上がることはないため, 基本 的に踏段が浮き上がり始めるときの $q\left(=q_{0}\right.$ : 初期踏段 
間隔拡大感度) が重要となる. $q_{0}$ は式(13)の $r$ を式(14) に代入することにより求めた $q$ の值であり,

$$
q_{0:}=\frac{y_{1}-b}{a-c+\sqrt{r_{F}^{2}-\left(y_{1}-d\right)^{2}}}-\frac{y_{1}}{\sqrt{r_{D}^{2}-y_{1}^{2}}}
$$

である. 図 10 中， $q_{0}$ を薄い線で示す．参考までに，踏 段浮き上がり後の踏段間隔拡大感度 $q$ の例として, $y_{1}=-200 \mathrm{~mm}(r=312.4 \mathrm{~mm})$ と $y_{1}=-100 \mathrm{~mm}(r=331.6 \mathrm{~mm})$ の場 合を示す。

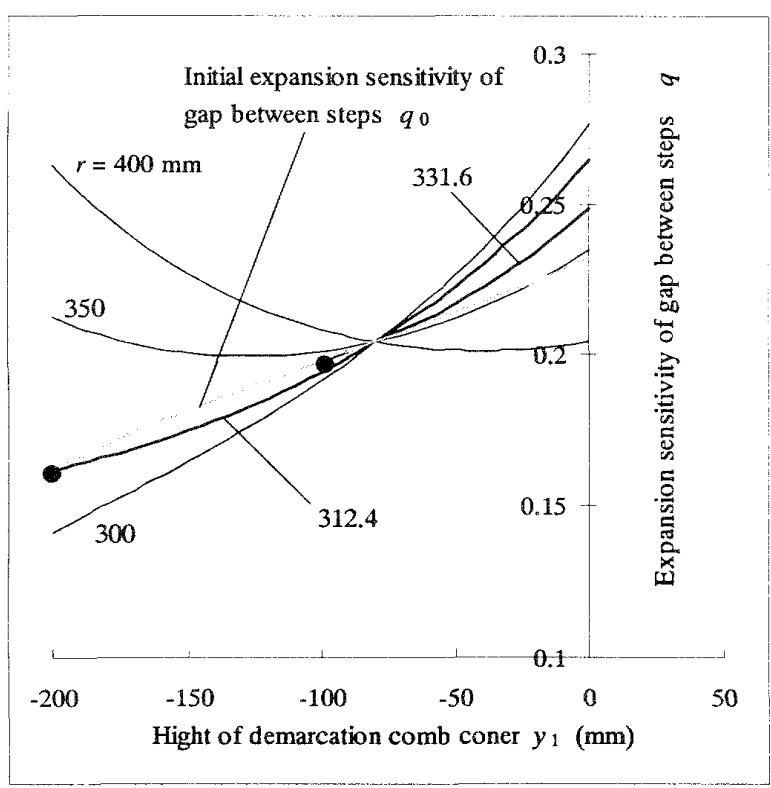

Fig.10 Relation between $y_{1}$ and $q$ when parameter is $r$

次に，初期踏段間隔抎大感度 $q_{0}$ が任意の值をとると きの点 B の位置を求める. 式(11)を用いて式(14)を書き 換えると,

$$
q=\frac{y_{1}-b}{a-x_{B}}-\frac{y_{1}}{\sqrt{r_{D}^{2}-y_{1}^{2}}}
$$

となる. 式(17)において, 駆動ローラの回転中心 A $(a$, b）之点 $\mathrm{D}$ の回転半径 $r_{\mathrm{D}}$ は定数であるから, $q$ の值を決 めることにより， $y_{1}$ と $x_{\mathrm{B}}$ の関係 (点 B の軌跡) を求め ることができる. したがってて, 式(17)の左辺を $q_{0}$ (一定 值）とすれば，点 B の軌跡として，初期踏段間隔拢大 感度 $q_{0}$ が一定となる曲線，すなわち，初期踏段間隔拡 大感度 $q_{0}$ が一定のライザークリート表面形状を求める ことができる. 式(17)から， $q=q_{0}$ としたときの $y_{1}$ と $x_{\mathrm{B}}$ の関係は,

$$
x_{B}=\frac{\left(q_{0} a+b-y_{1}\right) \sqrt{r_{D}^{2}-y_{1}^{2}}+a y_{1}}{y_{1}+q_{0} \sqrt{r_{D}^{2}-y_{1}^{2}}}
$$

となる. 図 11 は, $a=-60 \mathrm{~mm}, b=-80 \mathrm{~mm}, r_{\mathrm{D}}=400 \mathrm{~mm}$ と したときに, 初期踏段間隔拡大感度 $q_{0}$ をパラメータと して, $q_{0}$ が一定となる点 $\mathrm{B}\left(x_{\mathrm{B}}, y_{1}\right)$ の軌跡，すなわ方, $q_{0}$ 一定のライザークリート表面形状を示すものである.

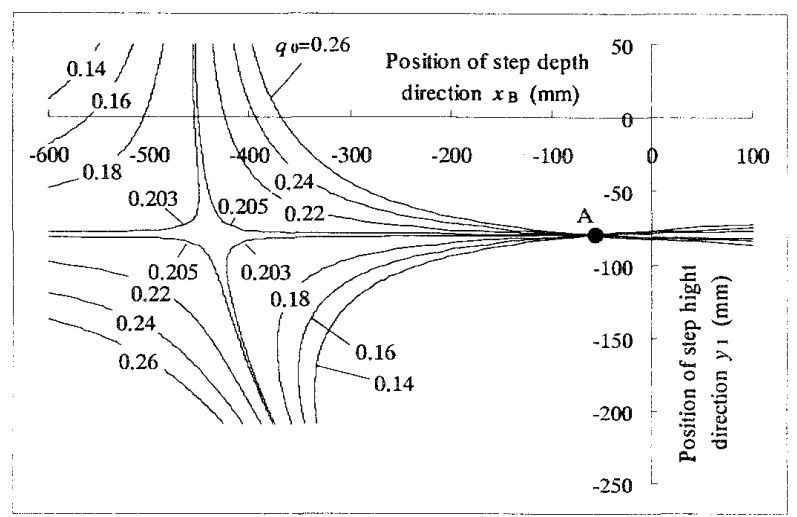

Fig.11 Locus that $q_{0}$ is constant

すべての曲線は点 A を通過しており,これは, 式(18) の $q_{0}$ を式(15)の $q_{\mathrm{b}}$ とおくことにより解析的に証明する ことができるが， $q_{0}=q_{\mathrm{b}}=0.204$ (図では0.203と 0.205 の場合を記載）の場合に極限值的に現れる十文字の軌 跡は解析的に求めることはできない，図から， $y_{1}>b$ の 領域では， $x_{\mathrm{B}}$ の值が小さくなるほど $q_{0}$ の值が小さくな り (踏段間隔が開き難い)， $y_{1}<b$ の領域では， $x_{\mathrm{B}}$ の值が 大きいほど $q_{0}$ の值が小さくなっている. したがって, 踏段が浮き上がる場合にも浮き上がらない場合にも靴 先等が噛み込みにくい踏板前端部とライザークリート の噒み合せ構造について総合的に考えると, ライザー の下部では，第 1 の噛み込みメカ二ズムによる噛み込 みを防止するために必要最小限の噛み合せ代を確保し， ライザー上部では，噛み合せ代をできるだけ大きくと れば良い（強度が許す範囲でライザークリートをでき るだけ高くす犼良い) と言える.したがって，ライ ザークリートの表面形状を円弧とする場合には，ライ ザー下部から上部にかけて徐々に噛み合せが深くなる ように円弧中心を定めれば良い。

\section{4. 結 言}

本論文では，エスカレーターの踏段間（噛みあわせ 構造部) への靴先などの噛み込み事故に対する安全対 策の一つの考え方として，噛み込み難さの向上（梳き 上げ効果の向上）を図るという場合を仮定して踏段の ライザー形状に関する理論検討をおこなった. その結 果,

1)上段側踏段が浮き上がらない場合に噛み込み難さを 
向上させるためには踏段の段差が小さくなるほど踏 板前端コーナー部とライザークリートの噛み合わせ を深くするか維持する必要があるが, これを実現す るための設計方針として, ライザークリート表面形 状を規定する円弧中心の $y$ 座標の制約条件を明らか にした.

2)上段側踏段が浮き上がる場合の踏段間隔拡大感度は, ライザー下部ではライザークリート表面の位置が上 段踏段側へいくほど小さく, ライザー上部では下段 踏段側へいくほモ゙小さくなり，噛み込み難くなる.

3)上記 1)，2)より，踏板前端とライザークリートの噛 み合せは，基本的にライザ一の上部へいくほど大き くなるように設定すれば良い。

尚, 本論文は，あくまで，䛧み込み難さ（梳き上げ 効果）に着目し, 踏段間への噛み込みの発生を低く抑 えるためにはどうするべきかについて実施した理論 検討であり, 今後, 実用化を目指す場合には, 万が一 噛み込んだ場合の引き抜き難さ等, 総合的な検討, 評 価が必要である.

\section{文献}

(1) Nakajima,M., Step of escalator (in Japanese), Japanese Patent Disclosure JP,H03-284594,A(1991).

(2) Sugita,K. Kitamura,S., Step of escalator (in Japanese), Japanese Patent Disclosure ,JP,S61-192689,A(1986)

(3) Ogura,M. Haruta,Y. Yoshikawa,T. Anshita,H., Study on Curved Rail Safety Device of Escalator, Transactions of the JSME, Vol.73,No.726, C(2007),pp.385-391 